Nama: Rismawati

Nim: 90100118032

Kelas Ekonomi Islam A

\title{
KONSEP EKONOMI PADA MASA NABI MUHAMMAD SAW
}

Konsep ekonomi syariah bukan sekedar sistem tentang perdagangan yang mengejar kenikmatan dunia semata, namun konsep ini secara total menekankan aspek ibadah duniawi yang menjunjung tinggi nilai etika interaksi dan moralitas syariah islam. ${ }^{1}$ Pada masa Rasulullah saw islam memberikan ruang yang sangat luas bagi berkembangnya perekonomian. Salah satu prinsip dasar dalam muamalah adalah bahwa segala sesuatu hukumnya mubah, kecuali jika ada dalil yang mengharamkannya, menjadi pendorong utama inovasi ekonomi yang mempercepat pertumbuhan ekonomi islam. Dari penjelasan tersebut, dapat di simpulkan bahwa yang dimaksud dengan ekonomi islam itu adalah sistem yang mengaplikasikan prinsip ekonomi yang sesuai dengan ajaran islam, bagi setiap kegiatan ekonomi bertujuan menciptakan barang dan jasa untuk memenuhi kebutuhan Indonesia. $^{2}$

Dalam prakteknya, Rasulullah SAW membangun suatu perekonomian yang dulunya dari titik nol menjadi suatu perekonomian raksasa yang mampu menembus keluar dari jazirah Arab. Pemerintahan yag di bangun Rasulullah saw di Madinah mampu menciptakan suatu aktivitas perekonomian yang membawa kemakmuran dan keluasan pengaruh pada masa itu. Kegiatan ekonomi telah menjadi sarana pencapaian kesejahteraan atau kemakmuran. Nabi Muhammad SAW memperkenalkan sistem ekonomi islam. Hal ini berawal dari kerja sama antara kaum Muhajirin dan Anshar. Sistem ekonmi islam yang di perkenalkan, antara lain, syirkah, qirad, dan khiyar dalam perdagangan. Selain itu, di

\footnotetext{
${ }^{1}$ Samsuduha." wisata halal sebagai implementasi konsep ekonomi syariah", Al-tafaqquh:journal of Islamic law, 1.1 (2020): hlm 20

2 Dewi maharani."ekonomi islam:solusi terhadap masalah sosial-ekonomi". Intiqad: jurnal agama dan pendidikan islam 10.1 (2018) 22-23
} 
perkenalkan sistem musaqah, mukhabarah, dan muzara'ah dalam bidang pertanian dan perkebunan. Para sahabat juga melakukan perdagangan dengan penuh kejujuran. Mereka tidak mengurangi timbangan dalam berdagang. Semenjak hijrah ke Madinah, kehidupan telah banyak berubah. Para sahabat Nabi Muhammad SAW dari kaum muhajirin bahu membahu dengan penduduk lokal madinah dari kaum Anshar dalam membangun kegiatan ekonomi. Berbagai bidang digeluti oleh beliau dan para sahabatnya baik itu pertanian, perkebunan, perdagangan dan peternakan. Pasar-pasar dibangun di Madinah. Kebun-kebun kurma menghasilkan panenan yang melimpah. Peternakan kambing menghasilkan susu yang siap dipasarkan maupun hanya sekedar untuk diminum. Dalam sejarah, dikenal tokoh islam yang terkenal dengan kekayaannya dan kepiawaiannya dalam berdagang dan berbagai bidang lainnya. ${ }^{3}$ Ekonomi islam memandang bahwa pasar, Negara, dan individu berada dalam keseimbangan (iqtishad), tidak bileh ada $s u b$ ordinat, sehingga salah satunya menjadi menjadi dominan dari yang lain. pasar dijamin kebebasannya dalam sistem islam. Pasar bebas menentukan cara-cara produksi, konsumsi, distribusi dan harga selama tidak ada pelanggaran syariah. ${ }^{4}$

\section{DAFTAR PUSTAKA}

Samsuduha, S. (2020). Wisata Halal Sebagai Implementasi Konsep Ekonomi Syariah. Al-Tafaqquh: Journal of Islamic Law, 1(1), HLM 20

Maharani, D. (2018). Ekonomi Islam: Solusi Terhadap Masalah Sosial-Ekonomi. Intiqad: Jurnal Agama dan Pendidikan Islam, 10(1), 22-23

Almizan, A. (2016). Distribusi Pendapatan: Kesejahteraan Menurut Konsep Ekonomi Islam. Maqdis: Jurnal Kajian Ekonomi Islam, 1(1), 76

H. idris parakkasi, kamiruddin."analisis harga dan mekanisme pasar dalam perspektif islam”. Jurnal Laa Maysir, volume 5 No. 12018 hlm 112

\footnotetext{
${ }^{3}$ Almizan."distribusi pendapatan:kesejahteraan menurut konsep ekonomi islam." Jurnal kajian ekonomi islam 1.1 (2016): 76

${ }^{4} \mathrm{H}$. idris parakkasi, kamiruddin."analisis harga dan mekanisme pasar dalam perspektif islam". Jurnal Laa Maysir, volume 5 No. 12018 hlm 112
} 
